\title{
Fabrication and Characterization of Thin-Film SOFC Supported by Microchannel-Structured Zirconia Substrate for Direct Methane Operation
}

\author{
Myongjin Lee, Yun Gan, Chunyang Yang, Chunlei Ren and Xingjian Xue* \\ Department of Mechanical Engineering, University of South Carolina, Columbia, SC 29208, USA
}

\begin{abstract}
ARTICLE INFO
Article Type: Research Article

Keywords:

Stability

Ni-ZrSDC Anode

Hydrocarbon Fuels

Microtubular SOFC

Microchanneled Inert Support

Timeline:

Received: August 20, 2021

Accepted: September 20, 2021

Published: October 12, 2021

Citation: Lee M, Gan Y, Yang C, Ren C, Xue X. Fabrication and Characterization of Thin-Film SOFC Supported by Microchannel-Structured Zirconia Substrate for Direct Methane Operation. Int J Petrol Technol. 2021; 8: 8092.
\end{abstract}

DOl: https://doi.org/10.15377/2409-787X.2021.08.6

\begin{abstract}
Ni-cermet anode demonstrates excellent catalytic activity and electrical conductivity but suffers from carbon deposition issues. To utilize Ni-cermet anode while preventing carbon deposition, a synergic strategy is employed to design anode electrodes. In particular, $\mathrm{Zr}$ is incorporated into $\mathrm{Ce}_{0.8} \mathrm{Sm}_{0.2} \mathrm{O}_{2-\delta}$ lattice to tailor oxygen storage and catalytic properties of $\mathrm{Ni}-\mathrm{Ce}_{0.8-x} \mathrm{Sm}_{0.2} \mathrm{Zr}_{x} \mathrm{O}_{2-\delta}$ anode for improving electrochemical oxidization of various fuel species. An inert thick YSZ microtubular substrate with radially well-aligned microchannels open at the inner surface supports multi-thin functional layers of solid oxide cell, i.e., $\mathrm{Ni}$ current collector, $\mathrm{Ni}-\mathrm{Ce}_{0.8-\mathrm{x}} \mathrm{Sm}_{0.2} \mathrm{Zr}_{x} \mathrm{O}_{2-\delta}$ anode, YSZISDC electrolyte, and LSCF cathode. The thick YSZ substrate inhibits the ratio of fuel to product gases in the thin anode functional layer, which favors the prevention of carbon build up in the thin anode layer when synergistically combined with $\mathrm{Ni}-\mathrm{Ce}_{0.8-x} \mathrm{Sm}_{0.2} \mathrm{Zr}_{x} \mathrm{O}_{2-\delta}$ anode material. The microchannels embedded in the YSZ substrate can also avoid too much fuel dilution in the anode functional layer. The cell is fabricated and tested with both hydrogen and methane as the fuel. A short-term test is conducted with methane as fuel, and good stability is obtained. The fundamental mechanisms for the prevention of carbon build up in the anode functional layer are also discussed.
\end{abstract}

*Corresponding Author Emails: xue@cec.sc.edu Tel: 803-576-5598

(C2021 Lee et al. Published by Avanti Publishers. This is an open access article licensed under the terms of the Creative Commons Attribution Non-Commercial License which permits unrestricted, non-commercial use, distribution and reproduction in any medium, provided the work is properly cited. (http://creativecommons.org/licenses/by-nc/4.0/) 


\section{Introduction}

Solid oxide fuel cell (SOFC) is an energy conversion device that converts chemical energy in fuels into electrical energy very efficiently and is environmentally friendly. SOFCs are fuel flexible that can use not only hydrogen but hydrocarbon fuels and even carbon [1-4]. Direct hydrocarbon-fueled SOFCs may provide advantages of eliminating external reforming components for SOFC systems and using the existing infrastructures for the production, storage, and delivery of hydrocarbon fuels. These would improve system efficiency, reduce system cost, and facilitate practical applications of SOFC technologies. The state-of-the-art anode material is Ni-cermet, a composite of $\mathrm{Ni}$ and electrolyte material. The $\mathrm{Ni}$ phase is an electronic conductor and catalyst, while the electrolyte phase is an ionic conductor. The catalytic activity of Ni enables the reforming of hydrocarbon fuels for producing syngas, a mixture of $\mathrm{H}_{2}$ and $\mathrm{CO}$, through catalytic oxidation, such as steam reforming and $\mathrm{CO}_{2}$ reforming as well as water-gas shift reaction. However, the high catalytic activity of $\mathrm{Ni}$ can also lead to the direct cracking of hydrocarbon compounds at high temperatures and CO hydrogenation as well as Boudouard reaction, causing carbon deposition in the anode. The carbon deposition, in turn, will deactivate active reaction sites, restrict gas flow, and damage microstructures, overall leading to severe degradations in anode performance and long-term stability [5-9]. Therefore, the carbon deposition issue in Ni-cermet anode electrode of hydrocarbonfueled SOFCs has been a major barrier towards practical applications.

Significant efforts have been made to modify Ni-cermet anodes to improve their properties for carbon deposition resistance. These include surface modification and alloying of $\mathrm{Ni}$-cermet with carbon-resistant metals and oxides, such as $\mathrm{Cu}, \mathrm{Sn}, \mathrm{Ag}, \mathrm{Ru}, \mathrm{W}, \mathrm{CeO}_{2}$, and their derivatives [10-19]. Despite these modifications, it is generally realized that the carbon deposition issue is inevitable for $\mathrm{Ni}$-based anodes due to the Ni-catalytic cracking of hydrocarbon fuels, especially in large-scale applications. Attempts have been made to develop Ni-free anode materials to circumvent the use of $\mathrm{Ni}$-based anode. These typically include a class of perovskite- and layered perovskite-type of mixed ionic and electronic conducting oxides, such as $\mathrm{La}_{0.75} \mathrm{Sr}_{0.25} \mathrm{Cr}_{0.5} \mathrm{Mn}_{0.5} \mathrm{O}_{3}, \mathrm{La}_{1}$. ${ }_{x} \mathrm{Sr}_{\mathrm{x}} \mathrm{TiO}_{3}, \mathrm{Sr}_{2} \mathrm{Mg}_{1-x} \mathrm{Mn}_{\mathrm{x}} \mathrm{MoO}_{6-\delta}, \operatorname{PrBaMn}_{2} \mathrm{O}_{5+\delta}$, and their derivatives [20-24]. Despite the fact that such materials demonstrated good properties as anodes for carbon deposition resistance, the power densities of corresponding SOFCs are usually much lower than Ni-cermet counterparts.

Further, complete conversion from hydrocarbon to syngas is hardly to achieve with such Ni-free anode materials. In this context, Ni-cermet is still a preferred anode material due to its high electronic conductivity and (electro)catalytic properties [25]. Another strategy to mitigate the carbon deposition issue is co-feeding a considerable amount of water with hydrocarbon fuels so that the oxygen to carbon ratio is maintained at a sufficiently high level in anode electrode. As a result, complete internal reforming of hydrocarbon fuels can be obtained. Meanwhile, it can also prevent Ni from being oxidized. However, too much water supply will dilute fuels in the anode, which in turn decreases open-circuit voltage and deteriorate the electrochemical performance of SOFCs. In this respect, precise control of operating temperature and oxygen to carbon ratio in the anode electrode may need much less water feeding. Nevertheless, the operation under precisely controlled thermodynamic conditions is possible but not practically feasible [26].

Recently, the concept of a diffusion barrier layer has been employed to increase diffusion resistance of hydrocarbon fuels into the anode functional layer and product gases (i.e., $\mathrm{H}_{2} \mathrm{O}, \mathrm{CO}_{2}$ ) out of the anode functional layer. As a consequence, the concentration ratio of product gases to hydrocarbon fuel in the anode functional layer will be high enough to suppress carbon build up in the anode functional layer [27-29]. On the one hand, the diffusion barrier layer increases fuel/gas diffusion resistance and concentration polarization loss of the anode; on the other hand, the high concentration ratio of product gases to hydrocarbon fuel will dilute fuels in the anode functional layer. Both of the effects will deteriorate the electrochemical performance of SOFCs. Therefore, a trade off is needed between carbon deposition suppression and good electrochemical performance when the diffusion barrier layer is employed for anode electrodes. One strategy for such a trade off could be obtained through a synergistic combination of a diffusion barrier layer and suitable Ni-cermet anode material. The diffusion barrier layer is used to tune carbon/oxygen ratios without diluting fuels too much in the anode functional layer. This requires that the porous microstructure of barrier layers enable facile fuel/gas diffusions. The Ni-cermet anode material should possess sound oxygen storage and catalytic properties, enabling full electrochemical oxidization 
of fuel species. As a result, $\mathrm{H}_{2} \mathrm{O}$ and $\mathrm{CO}_{2}$ produced by full oxidization of fuel would suppress carbon build up through backward Boudouard reaction and hydrogenation.

Cerium oxide exhibits the property of releasing and incorporating oxygen [30-31]. When aliovalent ions (divalent or tetravalent cations) are doped into ceria lattice, it may create oxygen vacancies by charge compensation mechanism, further improving oxygen storage capacity and catalytic property of ceria [32-34]. In this research, $\mathrm{Zr}$ and $\mathrm{Sm}$ were co-doped into ceria lattice and $\mathrm{NiO}-\mathrm{Ce}_{0.8-\mathrm{x}} \mathrm{Sm}_{0.2} \mathrm{Zr}_{\mathrm{x}} \mathrm{O}_{2-\delta}\left(\mathrm{NiO}: \mathrm{Ce}_{0.8-\mathrm{x}} \mathrm{Sm}_{0.2} \mathrm{Zr}_{x} \mathrm{O}_{2-\delta}=\right.$ 50\%:50\% in weight; $x=0,0.05,0.10,0.15$, and 0.20 , or simply denoted as NiO-ZrxSDC) as anode materials were systematically studied. The $\mathrm{Zr}$ doping level that minimizes polarization resistance of NiO-ZrxSDC anode was identified. A microtubular YSZ inert substrate was fabricated using an in-house built spinning extrusion system, featuring radially well-aligned microchannels open at the inner surface. Built upon the microtubular YSZ substrate and the identified NiO-ZrO.1SDC anode material, inert YSZ substrate supported cell of YSZ substrate/NiO/NiO$\mathrm{Zr0.1SDC/YSZ/Ce} 0.8 \mathrm{Sm}_{0.2} \mathrm{O}_{1.9} / \mathrm{La}_{0.6} \mathrm{Sr}_{0.4} \mathrm{CO}_{0.2} \mathrm{Fe}_{0.8} \mathrm{O}_{3-\delta}$ was fabricated through dip-coating and sintering process alternatively. The combination of such a cell design with NiO-Zr0.1SDC anode material is expected to suppress carbon deposition in the anode functional layer, thereby achieving stable electrochemical performance with hydrocarbon fuels.

\section{Experimental}

\subsection{Material Synthesis}

All the chemicals used in the experiments were purchased from Alfa Aesar and used as-purchased unless otherwise specified. The anode powders of $50 \% \mathrm{NiO}-50 \% \mathrm{Ce}_{0.8-\mathrm{x}} \mathrm{Sm}_{0.2} \mathrm{Zr}_{\mathrm{x}} \mathrm{O}_{1.9}(\mathrm{NiO}-\mathrm{ZrXSDC}$ ) in weight were synthesized by a urea combustion method in one pot. Particularly, stoichiometric amounts of $\mathrm{NiO}\left(\mathrm{NO}_{3}\right)_{2} \cdot 6 \mathrm{H}_{2} \mathrm{O}$ (98.0\% purity), $\mathrm{Ce}\left(\mathrm{NO}_{3}\right)_{3} \cdot 6 \mathrm{H}_{2} \mathrm{O}\left(99.5 \%\right.$ purity), $\mathrm{Sm}\left(\mathrm{NO}_{3}\right)_{3} \cdot 6 \mathrm{H}_{2} \mathrm{O}(99.9 \%$ purity), Zirconyl nitrate solution (99.0\% purity), and urea $\left(\mathrm{CO}\left(\mathrm{NH}_{2}\right)_{2}\right)(99.0-100.5 \%$ purity) were dissolved into deionized water to form a solution. The solution was magnetically stirred for 3hrs, followed by heating on a hot plate until self-ignited. After self-sustaining combustion, ash-like material was obtained. The obtained ash was subsequently ground for $24 \mathrm{hrs}$ in an ethanol medium using a ball milling process with zirconia balls. After drying, the ash was calcinated at $1000^{\circ} \mathrm{C}$ in the air for $2 \mathrm{hrs}$ to form NiO-ZrxSDC phases. $\mathrm{La}_{0.6} \mathrm{Sr}_{0.4} \mathrm{CO}_{0.2} \mathrm{Fe}_{0.8} \mathrm{O}_{3-\delta}$ (LSCF) powders were synthesized by a glycine nitrate process. Briefly, stoichiometric amounts of $\mathrm{La}\left(\mathrm{NO}_{3}\right)_{3} \cdot 6 \mathrm{H}_{2} \mathrm{O}\left(99.9 \%\right.$ purity), $\mathrm{Sr}\left(\mathrm{NO}_{3}\right)_{2}\left(99.0 \%\right.$ purity), $\mathrm{Co}\left(\mathrm{NO}_{3}\right)_{3} \cdot 6 \mathrm{H}_{2} \mathrm{O}(97.7 \%$ purity), $\mathrm{Fe}\left(\mathrm{NO}_{3}\right)_{3} \cdot 9 \mathrm{H}_{2} \mathrm{O}$ (98.0-101.0\% purity) and glycine (99.5\% purity) were dissolved into deionized water to form a solution. The solution was magnetically stirred for 3hrs followed by heating on a hot plate until combustion, resulting in ash-like material. The obtained ash-like material was subsequently ground for $24 \mathrm{hrs}$ in ethanol medium using a ball milling process with zirconia balls. After drying, the ash was calcinated at $700^{\circ} \mathrm{C}$ in the air for 2 hrs to form the LSCF phase.

\subsection{Symmetric Button Cell Preparation}

The SDC powders (Fuel Cell Materials, USA) with the binder of $2 \%$ polyvinyl butyral in weight were mixed and ground in ethanol. After drying, the mixture of powder and binder was iso-statically cold-pressed at 600MPa to form an electrolyte substrate, resulting in a diameter of $\sim 10 \mathrm{~mm}$ and a thickness of $\sim 1 \mathrm{~mm}$. The green electrolyte substrate was then sintered at $1450^{\circ} \mathrm{C}$ in the air for $6 \mathrm{hrs}$ to form a dense SDC electrolyte. The surface of sintered SDC electrolyte substrate was mechanically polished using sand-papers and subsequently washed by anhydrous ethanol in an ultrasonic cleaner. The resulting thickness of SDC electrolyte substrates was about $400 \mu \mathrm{m}$. 5\% ethylcellulose ( $\mathrm{TCl}$, Japan) in weight was mixed with $95 \%$ a-terpineol $(\mathrm{TCl}$, Japan) in weight to form an organic solution. The synthesized fine powders (NiO-ZrxSDC, 66.67\% in weight) were then mixed with the organic solution (33.33\% in weight) to form electrode inks. The electrode inks were screen-printed onto either side of the dense SDC electrolyte substrate. After drying and aging, the electrode-electrolyte assembly was sintered at $1250^{\circ} \mathrm{C}$ in the air for $2 \mathrm{hrs}$ to form symmetrical cell NiO-ZrxSDC | SDC | NiO-ZrxSDC. Silver wire was attached to either side of the symmetrical cells using silver paste (Heraeus 2807) as a current collector and external wires for further electrochemical measurement. 


\subsection{Single Microtubular Cell Fabrication}

Microtubular YSZ inert substrate was first prepared. Briefly, polyethersulfone (PESf, Veradel 3000P, Solvay Specialty Polymers, USA; 3.5\% in weight) and polyvinylpyrrolidone (PVP, K30, CP, Sinopharm Chemical Reagent Co., China; $0.5 \%$ in weight) were dissolved in N-methyl-2-pyrrolidone (NMP, HPLC grade, Sigma Aldrich, USA; 21\% in weight) and ball-milled for $2 \mathrm{hrs}$ to form an organic mixture. Commercial YSZ powder (Tape grade, Fuel Cell Material, USA; $75.0 \%$ in weight) was added into the organic mixture and ball-milled for $48 \mathrm{hrs}$ to form a homogeneous extrusion slurry. The as-prepared slurry was de-aired for $10 \mathrm{~min}$ and then loaded into an in-house build spinneret extrusion system to obtain green microtubular substrate. The extrusion system and related extrusion process were detailed elsewhere [35-37]. The green substrate was sintered at $1100^{\circ} \mathrm{C}$ in the air for $3 \mathrm{hrs}$ to achieve sufficient mechanical strength for subsequent functional layer coatings of NiO, NiO-ZrO.1SDC, YSZ, SDC, and LSCF sequentially. In particular, $0.4 \%$ ethyl cellulose and $99.6 \%$ ethanol in weight were mixed together to form an organic solution. $16.0 \% \mathrm{NiO}$ (Fuel cell materials, USA) and 1.8\% potato starch (J.T. Baker, USA) powders in weight were then mixed with the organic solvent to form a NiO slurry. The sintered YSZ microtubular substrates were sealed at both ends using PTFE films and vertically immersed into the prepared NiO slurry for 30 seconds. After drying in the air for $12 \mathrm{hrs}$, the coated samples were calcinated at $600^{\circ} \mathrm{C}$ in the air for $30 \mathrm{~min}$ to burn out organics and bind the NiO layer onto the YSZ substrate. The preparation and coating of NiO-Zr0.1SDC slurry were similar to those of the NiO layer but calcined at $900^{\circ} \mathrm{C}$ in air for $1 \mathrm{hr}$. For YSZ electrolyte fabrication, $30 \% \mathrm{~B} 73210$ organic binder in weight (Ferro Electronics Materials, USA), 40\% $\alpha$-terpineol in weight, and 30\% ethanol in weight were first mixed to form an organic slurry. 17\% YSZ powders (Fuel cell materials, USA) in weight were then mixed with the organic slurry to form a YSZ slurry. The YSZ slurry was then dip-coated onto the NiO-Zr0.1SDC layer, followed by dip-coating a SDC layer in a similar way. After drying, the coated samples were sintered at $1400^{\circ} \mathrm{C}$ in the air for $4 \mathrm{hrs}$ to form half-cells. Finally, the LSCF cathode layer was fabricated. Specifically, an organic slurry was first prepared by mixing $63.0 \%$ 2-butanone, 31.0\% ethanol, $0.5 \%$ triethanolamine, $1.0 \%$ dibutyl phthalate, $1.0 \%$ polyethylene glycol 300 (ACROS, USA), and 3.5\% butvar B-98 (Spectrum, USA) in weight. 10.0\% LSCF powders were then mixed with the prepared organic slurry to form a LSCF cathode slurry. The LSCF cathode slurry was then dipcoated onto the half-cells. After drying, the coated samples were sintered at $950{ }^{\circ} \mathrm{C}$ in the air for $2 \mathrm{hrs}$ to form a single microtubular cell of YSZ substrate/NiO/NiO-ZSDC/YSZ/SDC/LSCF. The resulting cathode area was about 0.3 $\mathrm{cm}^{2}$. The silver paste was painted onto the cathode as a current collector. Silver wire was wound around the cathode and at either end of the anode substrate to serve as a current collector and external circuit.

\subsection{Characterization and Electrochemical Measurements}

The phase purity of the prepared powder materials was characterized and identified using the X-ray diffraction technique (XRD, D/MAX-3C) with Cu Ka radiation ( $\lambda=1.5406 \AA$ ) at room temperature with a scanning rate of $5^{\circ} \mathrm{min}^{-1}$ in the range of $20^{\circ} \leq 2 \theta \leq 80^{\circ}$. Microstructures of prepared samples and cells were characterized using scanning electron microscopy (SEM, Zeiss Ultra Plus FESEM, Germany). Microstructures and element distributions of prepared microtubular cells were also examined using SEM in combination with Energy-dispersive X-ray spectroscopy (EDS, Oxford Instruments detector).

The symmetrical cell prepared above was sealed in an alumina test chamber. A high-temperature tube furnace controlled the temperature of the chamber. The temperature of the furnace was increased from room temperature to $800^{\circ} \mathrm{C}$ at a rate of $2^{\circ} \mathrm{C} \mathrm{min}{ }^{-1}$ while nitrogen with the flow rate of $30 \mathrm{ml} \mathrm{min}^{-1}$ was supplied into the alumina chamber. Once the furnace temperature reached $800^{\circ} \mathrm{C}$, the supplied gas was switched from nitrogen to humidified hydrogen $\left(\sim 3 \% \mathrm{H}_{2} \mathrm{O}, 30 \mathrm{~cm}^{3} \mathrm{~min}^{-1}\right)$. Under this condition, the experiment lasted for $3 \mathrm{hrs}$, allowing the completion of $\mathrm{NiO}$ reduction to $\mathrm{Ni}$ in the electrodes. Electrochemical impedance spectra (EIS) of the symmetric cell were then measured using the Solartron1260/1297 electrochemical workstation. The EIS measurement was obtained from 800 to $600^{\circ} \mathrm{C}$ with a voltage perturbation of $10 \mathrm{mV}$ over the frequency range from $0.01 \mathrm{~Hz}$ to $1 \mathrm{MHz}$ under open circuit voltage conditions.

The fabricated microtubular cell was electrochemically tested from 600 to $800^{\circ} \mathrm{C}$. Both humidified hydrogen and methane were used as fuel, while ambient air was used as an oxidant. The surface of the cathode and anode electrode was coated with silver paste and encircled with silver wires as the current collectors. Ceramic paste (Aremco products, inc. USA) was used to seal and attach two alumina tubes to either end of the YSZ substrate of 
the cell. The procedure is detailed in the paper published elsewhere [35]. The temperature of the cell was controlled by a tube furnace (MTI, USA). Nitrogen gas was first supplied into the anode of the cell at room temperature. The cell was then heated up from room temperature to $800^{\circ} \mathrm{C}$ at the rate of $2^{\circ} \mathrm{C} \mathrm{min}^{-1}$. Once the cell temperature reached $800^{\circ} \mathrm{C}$, the gas supplied to the anode was switched from nitrogen to humidified hydrogen $\left(\sim 3 \% \mathrm{H}_{2} \mathrm{O}\right)$. The flow rate of hydrogen was controlled at $30 \mathrm{~cm}^{3} \mathrm{~min}^{-1}$ using a precision flowmeter (APEX). The reduction of $\mathrm{NiO}$ current collector layer and NiO-ZrO.1SDC anode functional layer under this condition lasted for 3hrs before electrochemical testing. The voltage-current $(V-I)$ curves and EIS were measured using a Solartron1260/1287 electrochemical workstation from 800 to $600^{\circ} \mathrm{C}$. The EIS measurements were performed with a voltage perturbation of $10 \mathrm{mV}$ over the frequency range from $0.01 \mathrm{~Hz}$ to $1 \mathrm{MHz}$ under open-circuit voltage conditions. Similarly, V-I curves and EIS of the cell were measured using methane as fuel with the flow rate of 30 $\mathrm{cm}^{3} \mathrm{~min}^{-1}$ in the temperature range of $600-800^{\circ} \mathrm{C}$. A short-term stability test was also carried out with methane as fuel at an operating temperature of $700^{\circ} \mathrm{C}$. The voltage of $0.7 \mathrm{~V}$ was applied to the cell while the time history of current cell density was recorded.

\section{Results and Discussion}

\subsection{Materials Characterization}

Fig. (1a) shows the XRD patterns of the synthesized NiO-Ce ${ }_{0.8-x} \mathrm{Sm}_{0.2} \mathrm{Zr}_{x} \mathrm{O}_{2-\delta}(\mathrm{NiO}-\mathrm{ZrxSDC}, \mathrm{x}=0.05,0.10,0.15$, and $0.20)$ powders. All characteristic diffraction peaks correspond to the NiO and ZrxSDC phases. No other phases could be detected, implying that Zr was totally dissolved into the SDC lattice. The XRD patterns further indicate very good chemical compatibility between $\mathrm{NiO}$ and ZrxSDC phases. Fig. (1) b) shows the XRD patterns of the powders in the $2 \theta$ range of $54-58^{\circ}$. It can be seen that the peak was shifted to the higher angles with increasing $\mathrm{Zr}$ dopant contents from $0.05 \% \mathrm{~mol}$ to $0.20 \% \mathrm{~mol}$, indicating the decrease of lattice volume. Since the atomic radius of $\mathrm{Zr}^{4+}(80 \AA)$ is smaller than that of $\mathrm{Ce}^{4+}(90 \AA)$, the $\mathrm{Zr}$ doping leads to the decreased lattice parameter.
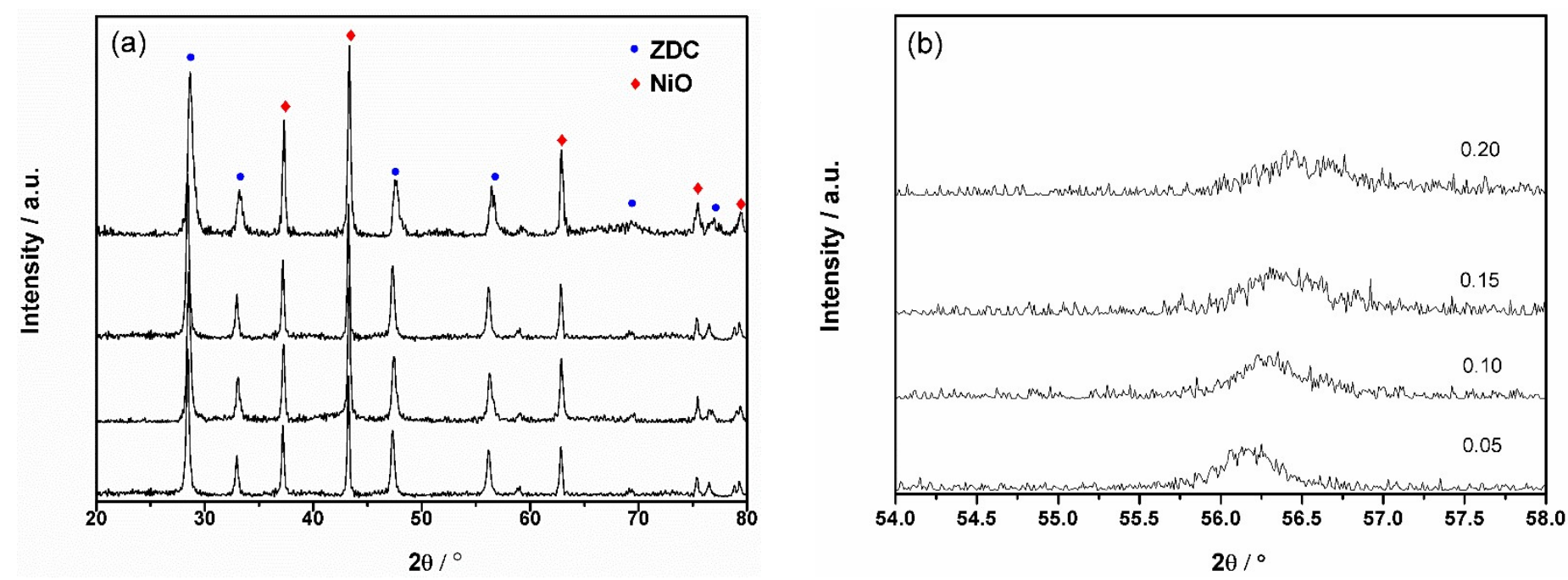

Figure 1: (a) XRD patterns of synthesized NiO-ZrxSDC powders in the $2 \theta$ range of $20-80^{\circ}$. (b) XRD patterns of the powders in the $2 \theta$ range of $54-58^{\circ}$.

Fig. (2) shows SEM images of the synthesized NiO-ZrxSDC powders. The powders consisted of fine and homogeneous particles with certain agglomerations. The average size of agglomerations is about $545 \mathrm{~nm}$. It seems that the agglomerations become weaker beyond the $\mathrm{Zr}$ doping level of 0.05 .

\subsection{Symmetry Cells}

Fig. (3) shows the polarization resistances $\left(R_{p}\right)$ values of the symmetrical cells Ni-ZrxSDC $|S D C| N i-Z r x S D C(x=0$, $0.05,0.10,0.15$, and 0.20 ) measured in humidified hydrogen at the temperatures of $600-800^{\circ} \mathrm{C}$. The $R_{p}$ values of 
different $\mathrm{Zr}$ doping levels at different temperatures were obtained from the equivalent circuit technique fitting from the EIS curves. The obtained $R_{p}$ values were then corrected by the electrode area and divided by two due to the symmetrical configuration of the cell. It can be seen that the polarization resistance tended to decrease with increasing $\mathrm{Zr}$ doping level in the range of 0 to $0.1 \% \mathrm{~mol}$ at every operating temperature. Beyond $0.1 \% \mathrm{~mol}$, the polarization resistance increased with increasing $\mathrm{Zr}$ dopant. The Ni-Zr0.1SDC electrode obtained the minimum polarization resistance among different Zr doping levels. In what follows, NiO-ZrO.1SDC will be used as anode material to fabricate microtubular YSZ inert substrate-supported single cell for electrochemical performance study.

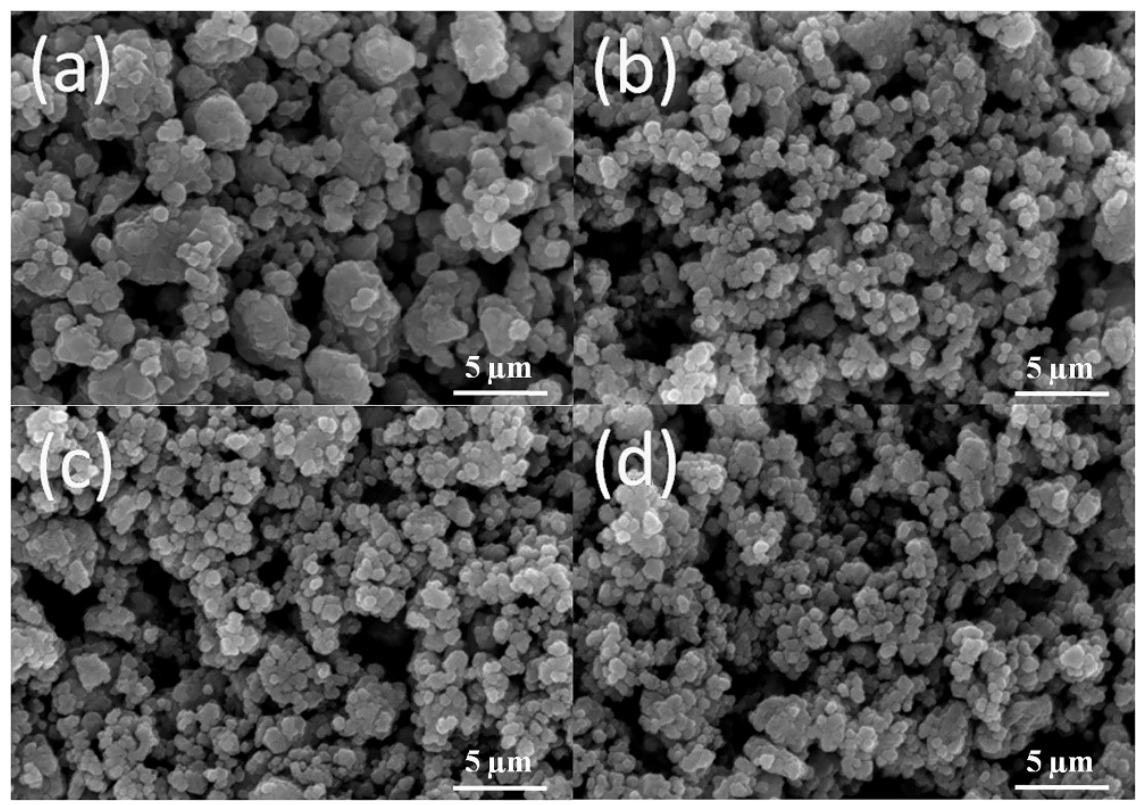

Figure 2: SEM images of the synthesized NiO-ZrxSDC powders. (a) $x=0.05$, (b) $x=0.10$, (c) $x=0.15$ and (d) $x=0.20$.

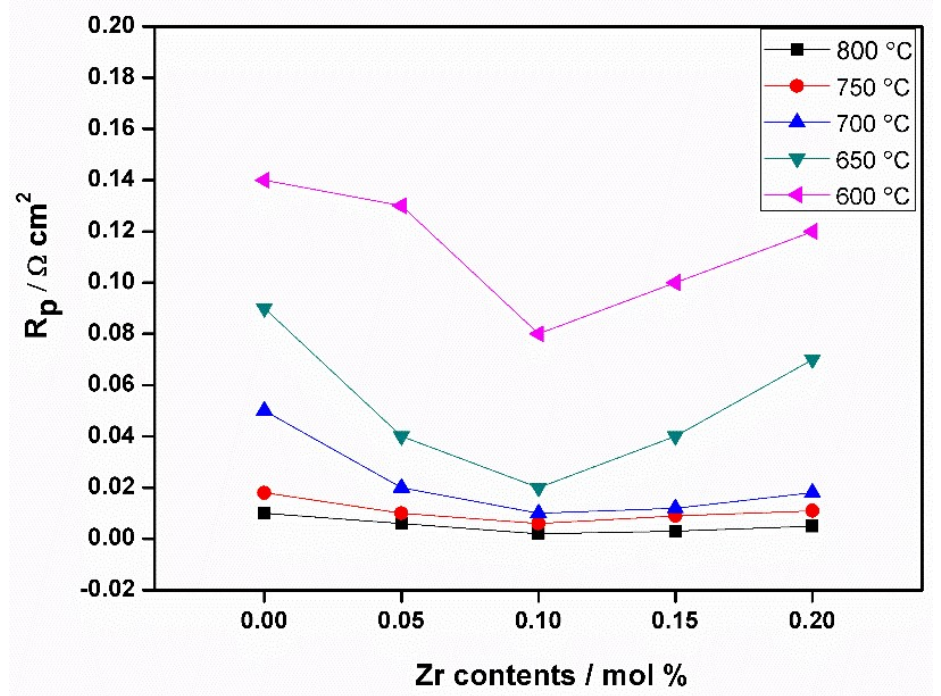

Figure 3: Polarization resistance $\left(R_{p}\right)$ of the Ni-ZrxSDC electrode symmetry cell.

\subsection{Single-Cell Performances}

Fig. (4) shows a cross-sectional SEM image of the fabricated microtubular cell YSZ substrate/NiO/NiOZr0.1SDC/YSZ/SDC/LSCF. It can be seen that radially well-aligned microchannels were embedded in the thick YSZ substrate, which is open at the inner surface (Fig. 4a). Multiple functional layers can also be observed on the thick YSZ substrate, including $\sim 3 \mu \mathrm{m} \mathrm{NiO} \mathrm{current} \mathrm{collector} \mathrm{layer,} \sim 4 \mu \mathrm{m}$ NiO-Zr0.1SDC anode functional layer, $\sim 10 \mu \mathrm{m}$ YSZ 
electrolyte layer, $\sim 5 \mu \mathrm{m}$ SDC buffer layer, and $\sim 10 \mu \mathrm{m}$ LSCF cathode layer (Fig. 4b). Intimate adhesions were obtained between different layers. The YSZ electrolyte layer is very dense. The SDC layer contains closed pores but is good enough as a buffer layer to separate the YSZ electrolyte layer from the LSCF cathode layer, which allows avoiding chemical reactions between YSZ and LSCF at elevated temperatures. The NiO layers and NiO-Zr0.1SDC exhibited porous microstructure features, and the porosity would be further improved in these two layers after $\mathrm{NiO}$ is reduced to $\mathrm{Ni}$.

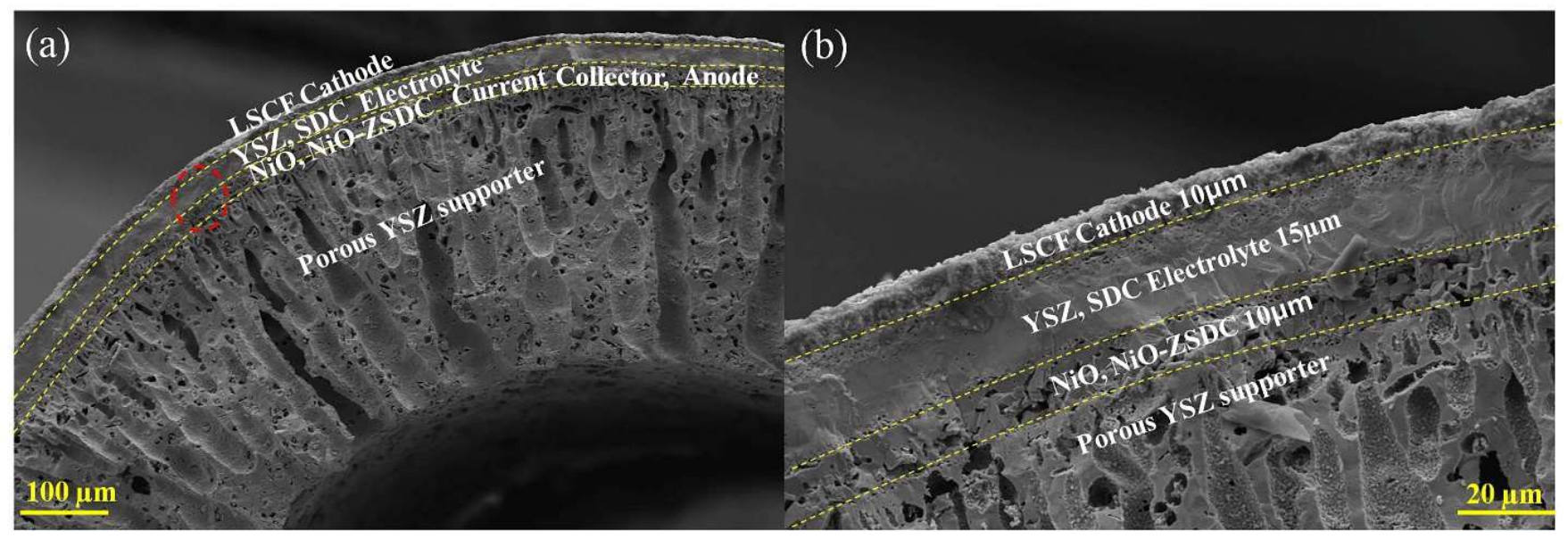

Figure 4: (a) SEM cross-sectional image of as-prepared porous YSZ supported single cell. (b) Enlarged SEM image of local area marked with the red circle in (a).

To examine the quality of the fabricated cell in a comprehensive manner, a benchmark test was first carried out. Before the test, the NiO current collector and NiO-Zr0.1SDC anode functional layer were first reduced. In particular, nitrogen with the flow rate of $30 \mathrm{~cm}^{3} \mathrm{~min}^{-1}$ was supplied to the anode side while the cell was heated up by a tube furnace. When the cell temperature reached $800^{\circ} \mathrm{C}$, the supplied nitrogen was switched to humidified hydrogen with a flow rate of $30 \mathrm{~cm}^{3} \mathrm{~min}^{-1}$. The experiment under this condition was lasted for $3 \mathrm{hrs}$, allowing for the completion of $\mathrm{NiO}$ reduction. The electrochemical performance of the cell was then measured in the temperature range of $800-600^{\circ} \mathrm{C}$, with the cathode electrode being exposed to ambient air. Fig. (5a) shows the corresponding voltage-current (V-I) curves and power density (P-I) curves. The OCVs of 1.01 to $0.94 \mathrm{~V}$ were obtained at the temperature range of $600-800^{\circ} \mathrm{C}$. These values are close to the theoretical Nernst potentials (e.g., $\sim 1.10 \mathrm{~V}$ ) when YSZ is employed as electrolyte material, indicating that the YSZ electrolyte is dense and the rest of the cell components functioned well. The results further imply that the process for cell fabrication is reliable. The peak power density of the cell reached about 204, 272, 385, 500, and $602 \mathrm{~mW} \mathrm{~cm}^{-2}$ at $600,650,700,750$, and $800^{\circ} \mathrm{C}$, respectively. The EIS curves of the cell measured at OCV conditions are shown in Fig. (5b). Using equivalent circuit and curve-fitting technique, the ohmic resistance $\left(R_{\text {ohm }}\right)$ and polarization resistance $\left(R_{p}\right)$ of the cell were obtained from EIS curves and listed in Table 1. As one can see that with increasing the operating temperature from 600 to $800^{\circ} \mathrm{C}$, the cell $R_{\text {ohm }}$ decreased from 0.93 to $0.25 \Omega \mathrm{cm}^{2}$ while the cell $R_{p}$ decreased from 1.12 to $0.23 \Omega \mathrm{cm}^{2}$, respectively. The $R_{\text {ohm }}$ is contributed by electrolyte and the skeleton of porous anode and cathode electrode as well as associated current collectors. The increasing temperature would directly reduce ohmic resistances of YSZ

Table 1: Open circuit voltage (OCV), ohmic resistance (Rohm), polarization resistance ( $\left.R_{p}\right)$, maximum power density (MPD) of the single cell in hydrogen at different temperatures.

\begin{tabular}{|c|c|c|c|c|c|}
\hline Temperature $/{ }^{\circ} \mathbf{C}$ & $\mathbf{8 0 0}$ & $\mathbf{7 5 0}$ & $\mathbf{7 0 0}$ & $\mathbf{6 5 0}$ \\
\hline \hline $\mathrm{OCV} / \mathrm{V}$ & 0.94 & 0.96 & 0.988 & 1.00 \\
\hline $\mathrm{MPD} / \mathrm{mWcm}$ & -2 & 500 & 385 & 272 & 204 \\
\hline $\mathrm{R}_{\mathrm{ohm}} / \Omega \mathrm{cm}^{2}$ & 602 & 0.46 & 0.71 & 0.82 & 0.93 \\
\hline $\mathrm{R}_{\mathrm{p}} / \Omega \mathrm{cm}^{2}$ & 0.25 & 0.45 & 0.67 & 1.12 \\
\hline
\end{tabular}



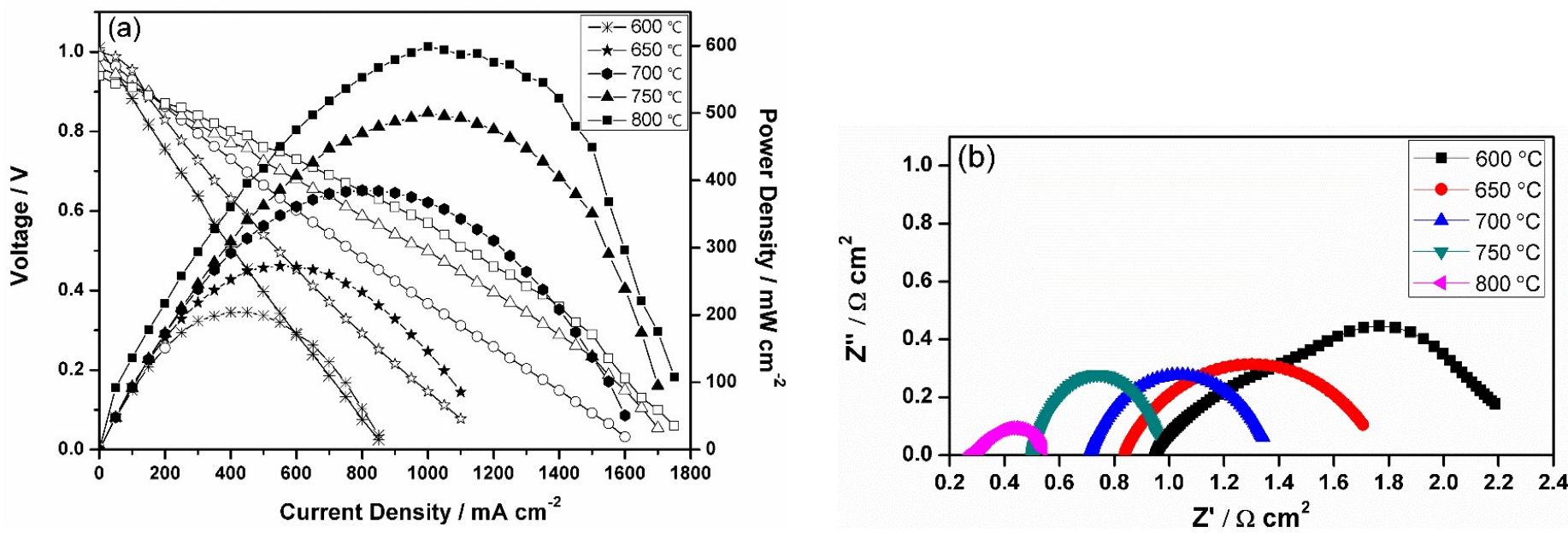

Figure 5: (a) V-I curves and power density curves of the single cell in hydrogen. (b) EIS curves of the single cell in hydrogen under open circuit voltage conditions.

electrolyte and Ni-Zr0.1SDC anode as well as LSCF cathode skeletons; therefore, the cell $R_{\text {ohm }}$ decreased. Similarly, higher temperatures would enhance the electrochemical kinetic properties of both anode and cathode electrodes, including surface exchange coefficients and bulk diffusivities. Accordingly, the cell $R_{p}$ decreased. Overall, the benchmark test results indicate that the cell obtained reasonably good electrochemical performance, confirming that the cell fabrication process is reliable. The electrochemical performance of the fabricated cell fueled with methane is then tested. The effectiveness of a synergistic combination of Ni-Zr0.1SDC anode material and cell architecture for suppression of carbon deposition is further examined.

Shown in Fig. (6a) are V-I curves and P-I curves of the cell directly fueled with methane in the temperature range of $600-800^{\circ} \mathrm{C}$. The cell obtained OCVs of 1.02, 1.01, 1.00, 0.98, and $0.967 \mathrm{~V}$ and peak power densities of 173, $259,327,384$, and $456 \mathrm{~mW} \cdot \mathrm{cm}^{-2}$ at the temperatures of $600,650,700,750$, and $800^{\circ} \mathrm{C}$, respectively. Fig. (6b) shows the EIS curves of the cell under open-circuit voltage conditions. Using equivalent circuit and curve-fitting technique, the cell ohmic resistance $\left(R_{\text {ohm }}\right)$ and polarization resistance $\left(R_{p}\right)$ were obtained from the measured EIS curves. The results are summarized in Table 2 . In particular, the ohmic resistance of $0.45,0.52,1.05,1.57$, and 1.98 $\Omega \mathrm{cm}^{2}$ and the polarization resistance of $0.47,0.51,0.89,1.23$, and $1.43 \Omega \mathrm{cm}^{2}$ were obtained at the temperatures of $600,650,700,750$, and $800^{\circ} \mathrm{C}$, respectively.
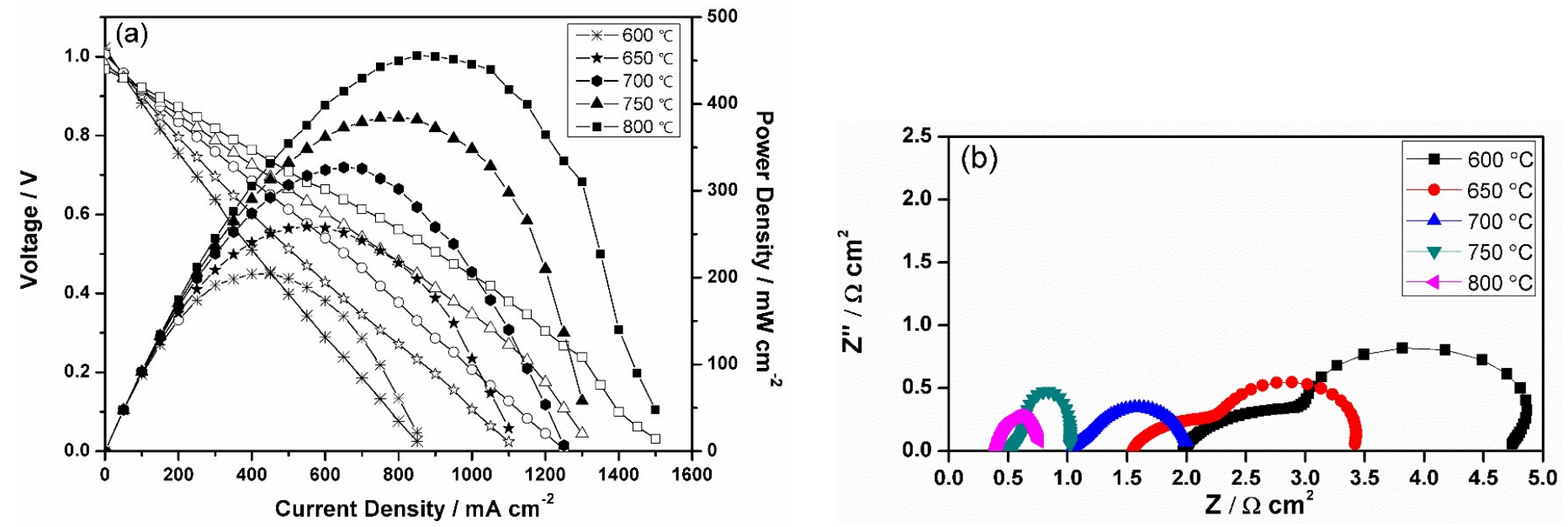

Figure 6: (a) V-I curves and power density curves of the single cell in methane. (b) EIS curves of the single cell in methane under open circuit voltage conditions.

To examine the stability of the cell directly fueled with methane, a short-term durability test was carried out. The temperature of the cell was controlled at $700^{\circ} \mathrm{C}$. The voltage of $0.7 \mathrm{~V}$ was applied to the cell while the current 
of the cell was monitored. Under these conditions, the experiment was run for about 26hrs. The history of current cell density is shown in Fig. (7). It is obvious to see that the current density of the cell was very stable, performance degradations could not be observed. It is noteworthy that methane-fueled YSZ inert substrate-supported SOFC has been studied in the open literature [38], where Ni-SDC was used as anode functional layer material, and the porosity of YSZ substrate was randomly distributed without any radially well-aligned microchannels. Nevertheless, the corresponding cell showed a voltage loss of $9 \%$ during short-term stability of $13 \mathrm{hrs}$ at $700^{\circ} \mathrm{C}$ in methane. Comparing our results mentioned above with those in [38], it seems to indicate that the combination of $\mathrm{Zr}$ doped SDC anode material and YSZ inert substrate embedded with radially well-aligned microchannels is able to effectively improve the performance stability of the cell directly fueled with methane. After the short-term durability test, the cell was further characterized. Shown in Fig. (8a) is the cross-sectional SEM image of the posttest microtubular cell ranging from part of the YSZ substrate to part of the dense YSZ electrolyte.

Table 2: Open circuit voltage (OCV), ohmic resistance $\left(R_{\text {ohm }}\right)$, polarization resistance $\left(R_{p}\right)$, maximum power density (MPD) of the single cell in methane at different temperatures.

\begin{tabular}{|c|c|c|c|c|c|}
\hline Temperature $/{ }^{\circ} \mathrm{C}$ & 800 & 750 & 700 & 650 & 600 \\
\hline $\mathrm{OCV} / \mathrm{V}$ & 0.967 & 0.98 & 1.00 & 1.01 & 1.02 \\
\hline $\mathrm{MPD} / \mathrm{mWcm}^{-2}$ & 456 & 384 & 327 & 259 & 173 \\
\hline $\mathrm{R}_{\mathrm{ohm}} / \Omega \mathrm{cm}^{2}$ & 0.45 & 0.52 & 1.05 & 1.57 & 1.98 \\
\hline $\mathrm{R}_{\mathrm{p}} / \Omega \mathrm{cm}^{2}$ & 0.47 & 0.51 & 0.89 & 1.23 & 1.43 \\
\hline
\end{tabular}

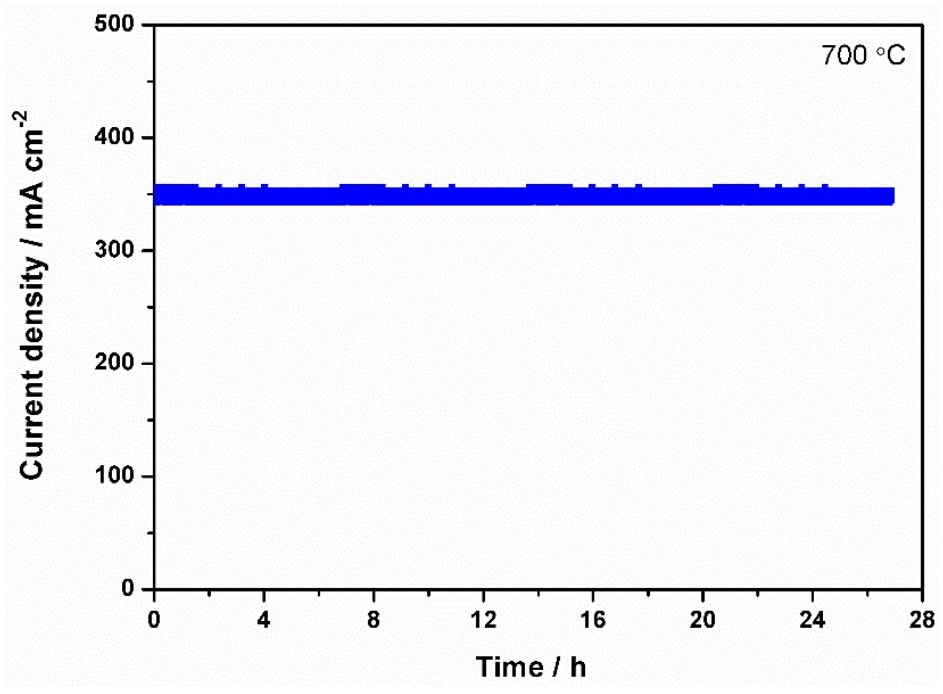

Figure 7: Short-term performance stability of the single cell in methane fuel at $0.7 \mathrm{~V}$ and $700^{\circ} \mathrm{C}$.

The radially well-aligned microchannels in the YSZ substrate still can be observed. The Ni current collector layer and Ni-Zr0.1SDC anode functional layer can be identified and show intimate contact with one another. Further EDS analysis indicates that $\mathrm{Ni}$ elements are mainly confined within the Ni-current collector layer and Ni-Zr0.1SDC anode functional layer (Fig. 8b). Zr elements are mainly located in the substrate and YSZ electrolyte layer (Fig. 8d). Interestingly, C elements were primarily located in the substrate (Fig. 8c). Quantitative line EDS analysis (Fig. 8e) indicates that some carbon elements could still be detected in the $\mathrm{Ni}$ current collector layer but not in the $\mathrm{Ni}$ Zr0.1SDC anode functional layer. It is noteworthy that such a Ni current collector region is directly connected to a microchannel in the substrate, whereby methane diffusion to the current collector is relatively easy.

To understand the mechanisms and reactions in the anode and the prevention of carbon deposition in the anode functional layer, the experimental data mentioned above is further compared and interpreted from a theoretical point of view. When methane is employed as fuel for Ni-cermet anode, very complicated 
chemical/electrochemical reactions would take place. These could include the steam reforming reaction of $\mathrm{CH}_{4}$, the dry $\left(\mathrm{CO}_{2}\right)$ reforming reaction of $\mathrm{CH}_{4}$, and water gas shift reaction, as shown below, respectively,
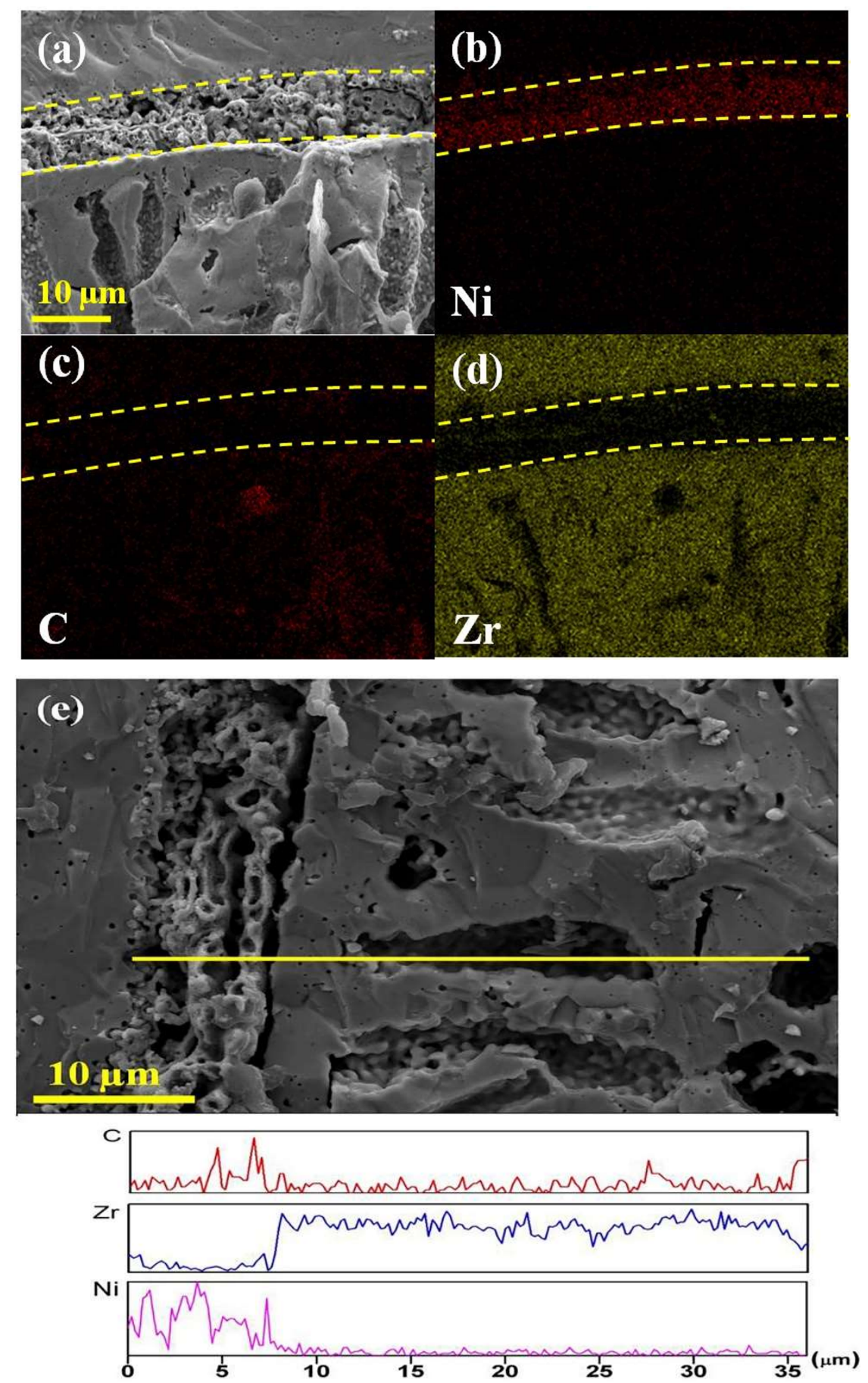

Figure 8: SEM and EDS images of the single cell after stability measurement. (a) Cross sectional SEM image of the single cell. (b) EDS mapping of Ni. (c) EDS mapping of C. (d) EDS mapping of Zr. (e) Location for line EDS characterization and C, Zr, Ni line EDS spectrum.

$$
\begin{aligned}
& \text { Steam reforming reaction: } \mathrm{CH}_{4}+\mathrm{H}_{2} \mathrm{O} \leftrightarrow \mathrm{CO}+3 \mathrm{H}_{2} \\
& \text { Dry reforming reaction: } \mathrm{CH}_{4}+\mathrm{CO}_{2} \leftrightarrow 2 \mathrm{CO}+2 \mathrm{H}_{2} \\
& \text { Water-gas shift reaction: } \mathrm{CO}+\mathrm{H}_{2} \mathrm{O} \leftrightarrow \mathrm{CO}_{2}+\mathrm{H}_{2}
\end{aligned}
$$


As a result, the fuel species of $\mathrm{H}_{2}$ and $\mathrm{CO}$ are generated from these three reactions, meanwhile $\mathrm{CO}_{2}$ is produced from the water gas shift reaction. Electrochemical oxidations of fuel species $\mathrm{CH}_{4}, \mathrm{H}_{2}$, and $\mathrm{CO}$ would then take place at triple phase boundaries (TPBs) in the anode functional layer by using oxygen ions released from the Zr0.1SDC phase. Depending on the amount of $\mathrm{CH}_{4}$ and oxygen ion $\left(\mathrm{O}^{2-}\right)$ available at TPB sites, both full and partial electrochemical oxidations could occur, specifically,

$$
\begin{aligned}
& \text { Full oxidation of } \mathrm{CH}_{4}: \mathrm{CH}_{4}+4 \mathrm{O}^{2-} \rightarrow \mathrm{CO}_{2}+2 \mathrm{H}_{2} \mathrm{O}+8 \mathrm{e}^{-} \\
& \text {Partial oxidation of } \mathrm{CH}_{4}: \mathrm{CH}_{4}+\mathrm{O}^{2-} \rightarrow \mathrm{CO}+2 \mathrm{H}_{2}+2 \mathrm{e}^{-} \\
& \qquad \begin{array}{c}
\mathrm{H}_{2}+\mathrm{O}^{2-} \rightarrow \mathrm{H}_{2} \mathrm{O}+2 \mathrm{e}^{-} \\
\mathrm{CO}+\mathrm{O}^{2-} \rightarrow \mathrm{CO}_{2}+2 \mathrm{e}^{-}
\end{array}
\end{aligned}
$$

According to the Nernst potential equation, the OCV of the cell is dependent on the partial pressures of oxidant at the cathode side and fuels at the anode side. Since three fuel species of $\mathrm{CH}_{4}, \mathrm{H}_{2}$, and $\mathrm{CO}$ directly involved in electrochemical oxidations through the reactions of (4) - (7), the OCV of the cell would be determined by these four reactions in a combinational way. Theoretically, it has been demonstrated that the OCVs for electrochemical oxidations of $\mathrm{H}_{2}$ and $\mathrm{CO}$, and the full electrochemical oxidation of $\mathrm{CH}_{4}$ decrease with increasing operating temperatures while that for partial electrochemical oxidation of $\mathrm{CH}_{4}$ increases distinctly [39]. As demonstrated above, the OCVs of the cell fueled with $\mathrm{H}_{2}$ decreased from 1.01 to $0.94 \mathrm{~V}$ when the temperature was increased from 600 to $800^{\circ} \mathrm{C}$, which is consistent with the theoretical predictions. With $\mathrm{CH}_{4}$ as fuel, the OCVs of the cell decreased from 1.02 to $0.967 \mathrm{~V}$ with increasing the temperature from 600 to $800^{\circ} \mathrm{C}$. This observation indicates that the OCVs contributed by the full electrochemical oxidations of $\mathrm{CH}_{4}, \mathrm{H}_{2}$, and $\mathrm{CO}$ outperformed the contribution from the partial electrochemical oxidation of $\mathrm{CH}_{4}$, and the latter is not a dominant reaction in the anode. As mentioned above, the type of electrochemical oxidations of $\mathrm{CH}_{4}$ is dependent on the concentrations of gas species $\mathrm{CH}_{4}$ and oxygen ion $\left(\mathrm{O}^{2-}\right)$ at TPB sites. According to the reactions (4) and (5), when $\mathrm{CH}_{4}$ concentration is relatively low while that of mobile $\mathrm{O}^{2-}$ near the TPB sites are relatively high, the full oxidation of $\mathrm{CH}_{4}$ would occur; in other extreme situations of high $\mathrm{CH}_{4}$ concentration and low concentration of mobile $\mathrm{O}^{2-}$, the partial oxidation of $\mathrm{CH}_{4}$ could take place. We have experimentally demonstrated that the microtubular substrate with radially well-aligned microchannels facilitates facile gas diffusion and is able to obtain very high gas permeability [35, 36]. Accordingly, sufficiently high $\mathrm{CH}_{4}$ concentration would be maintained in the anode functional layer. Since the full oxidation of $\mathrm{CH}_{4}$ in combination with the oxidations of $\mathrm{H}_{2}$, and $\mathrm{CO}$ outperformed the partial oxidation of $\mathrm{CH}_{4}$ in the anode functional layer, as demonstrated by the OCVs of the cell, it is reasonable to assume that sufficient oxygen ions are available for these reactions at the TPBs in the anode functional layer. This indicates the good oxygen storage capacity and catalytic property of the Zr0.1SDC phase, which is consistent with the above understanding of $\mathrm{Zr}$ doped SDC material.

When $\mathrm{CH}_{4}$ is directly utilized as fuel for SOFCs, carbon could be generated through three reactions, including direct cracking of $\mathrm{CH}_{4}$, Boudouard reaction, and hydrogenation, in particular,

$$
\begin{aligned}
& \text { Direct cracking of } \mathrm{CH}_{4}: \mathrm{CH}_{4} \leftrightarrow 2 \mathrm{H}_{2}+\mathrm{C} \\
& \text { Boudouard reaction: } 2 \mathrm{CO} \leftrightarrow \mathrm{CO}_{2}+\mathrm{C} \\
& \text { Hydrogenation: } \mathrm{CO}+\mathrm{H}_{2} \leftrightarrow \mathrm{H}_{2} \mathrm{O}+\mathrm{C}
\end{aligned}
$$

The reaction of $\mathrm{CH}_{4}$ direct cracking is usually obtained by Ni's excellent catalytic activity. For the studied microtubular cell, the $\mathrm{Ni}$ phase is confined within the thin Ni current collector layer and Ni-Zr0.1SDC anode functional layer. Since $\mathrm{H}_{2} \mathrm{O}$ and $\mathrm{CO}_{2}$ are produced only in the thin anode functional layer through electrochemical oxidization of fuels, which facilitates the reforming reactions of $\mathrm{CH}_{4}$ and water gas shift reaction, it is less likely for direct $\mathrm{CH}_{4}$ cracking (reaction (8)) to occur in the thin Ni-containing layers. Therefore, carbon could be produced only through the Boudouard reaction (9) and hydrogenation (10). When the concentrations of $\mathrm{H}_{2} \mathrm{O}$ and $\mathrm{CO}_{2}$ are relatively high, which is usually the case in the thin anode functional layer, the backward reactions of (9) and (10) would be favorited. As a result, carbon accumulation would be inhibited in the anode functional layer. This could 
be why the cell demonstrated very stable performance in the short-term test when directly fueled with methane. Depending on various species concentrations, the forward Boudouard reaction and hydrogenation could still occur in the YSZ microstructure substrate, and carbon could be built up in the substrate and current collector region near microchannels. This understanding is also consistent with the above EDS results of carbon element distribution.

\section{Conclusions}

A family of $\mathrm{NiO} 50 \%-\mathrm{Ce}_{0.8-x} \mathrm{Sm}_{0.2} \mathrm{Zr}_{x} \mathrm{O}_{2-\delta} 50 \%$ in weight $(\mathrm{x}=0.0,0.05,0.10,0.15,0.20)$ anode composite powders were successfully synthesized using urea combustion method in one pot. The $\mathrm{Zr}$ doping effects were systematically studied using symmetric cells in a reducing atmosphere at elevated temperatures. The $\mathrm{Zr}$ doping level of $x=0.1$ that minimizes the anodic polarization resistance of the composite anode was identified. Microtubular YSZ substrate was fabricated using an in-house built spinning extrusion system, featuring radially well-aligned microchannels open at the substrate inner surface. Built upon the fabrication of thick YSZ substrate, thin layers of $\mathrm{NiO}$ current collector, NiO-ZrO.1SDC anode, YSZ/SDC electrolyte, and LSCF cathode were sequentially fabricated through dip-coating/sintering process alternatively, forming a microtubular cell of YSZ substrate/NiO/NiO-Zr0.1SDC/YSZ/SDC/LSCF. The cell exhibited the peak power densities of 602 and $456 \mathrm{~mW} \mathrm{~cm}^{-2}$ at $800^{\circ} \mathrm{C}$ when ambient air was used as an oxidant, and humidified hydrogen and methane were used as fuel, respectively. The cell also exhibited very good performance stability in the 26 hrs short-term durability test at $700^{\circ} \mathrm{C}$ near the condition of peak power density output when directly fueled with methane. The capability of carbon deposition prevention was achieved through a synergistic combination of oxygen storage and catalytic properties of the Zr0.1SDC phase in the anode functional layer and novel architecture design of the cell. The fundamental mechanisms for carbon suppression are analyzed.

\section{References}

[1] Ormerod RM. Chem Soc Rev. 2003; 32: 17. https://doi.org/10.1177/1030570X0301600102

[2] Minh N. Solid State Ionics, 2004; 174: 271. https://doi.org/10.1016/j.ssi.2004.07.042

[3] Zhan Z, Barnett SA. Science, 2005; 308: 844. https://doi.org/10.1126/science.1109213

[4] Nakagawa N. Ishida M. Ind Eng Chem Res. 1988; 27: 1181. https://doi.org/10.1021/ie00079a016

[5] Yang L, Wang S, Blinn K, Liu M, Liu Z, Cheng Z, Liu M. Science 2009; 326: 126. https://doi.org/10.1126/science.1174811

[6] Takeguchi T, Kikuchi R, Yano T, Eguchi K, Murata K. Catal Today 2003; 84: 217. https://doi.org/10.1016/S0920-5861(03)00278-5

[7] Sumi H, Yamaguchi T, Hamamoto K, Suzuki T, Fujishiro Y. J Power Sources 2012; 220: 74. https://doi.org/10.1016/j.jpowsour.2012.07.106

[8] Kim Y, Kim JH, Bae J, Yoon CW, Nam SW. J. Phys Chem C 2012; 116: 13281. https://doi.org/10.1021/jp3035693

[9] Miao H, Liu G, Chen T, He C, Peng J, Ye S, Wang WG.J Solid State Electrochem. 2015; 19: 639. https://doi.org/10.1007/s10008-014-2640-7

[10] Myung J, Kim SD, Shin TH, Lee D, Irvine JTS, Moon J, Hyun SH. J Mater Chem A 2015; 3: 13801. https://doi.org/10.1039/C4TA06037G

[11] Zhu H, Wang W, Ran R, Shao Z. Int J Hydrog Energy, 2013; 38: 3741. https://doi.org/10.1016/j.ijhydene.2013.01.032

[12] Suzuki T, Yamaguchi T, Hamamoto K, Fujishiro Y, Awano M, Sammes N. Energy Environ Sci. 2011 ; 4 : 940. https://doi.org/10.1039/COEE00231C

[13] Wang K, Ran R, Shao Z. J Power Sources 2007; 170: 251. https://doi.org/10.1016/j.jpowsour.2007.03.070

[14] Yoon D, Manthiram A. Energy Environ Sci. 2014, 7, 3069. https://doi.org/10.1039/C4EE01455C

[15] Ma J, Jiang C, Connor PA, Cassidy M, Irvine JTS. J Mater Chem A 2015; 3: 19068. https://doi.org/10.1039/C5TA06421J

[16] Kim H, Lu C, Worrell WL, Vohs JM, Gorte RJ. J Electrochem Soc. 2002; 149: A247. https://doi.org/10.1149/1.1445170

[17] Nikolla E, Schwank J, Linic S. J Electrochem Soc. 2009; 156: B1312. https://doi.org/10.1149/1.3208060

[18] Wu X, Zhou X, Tian Y, Kong X, Zhang J, Zuo W. Int J Hydrog Energy 2015; 40: 16484. https://doi.org/10.1016/j.ijhydene.2015.09.121

[19] Qiao J, Zhang N, Wang Z, Mao Y, Sun K, Yuan Y. Fuel Cells, 2009; 9: 729. https://doi.org/10.1002/fuce.200800104

[20] Tao S, Irvine JTS. Nat Mater, 2003; 2: 320. https://doi.org/10.1038/nmat871

[21] Atkinson A, Barnett S, Gorte RJ, Irvine JTS, McEvoy AJ, Mogensen M, et al. Nat Mater. 2004; 3: 17. https://doi.org/10.1038/nmat1040

[22] Huang YH, Dass RI, Xing ZL, Goodenough JB. Science 2006; 312: 254. https://doi.org/10.1126/science.1125877

[23] Sengodan S, Choi S, Jun A, Shin TH, Ju YW, Jeong HY, et al. Nat Mater. 2015; 14: 205. https://doi.org/10.1038/nmat4166

[24] Dong G, Yang C, He F, Jiang Y, Ren C, Gan Y, et al. RSC Adv. 2017; 7: 22649. https://doi.org/10.1039/C7RA03143B

[25] Wang W, Su C, Wu Y, Ran R, Shao Z. Chem Rev. 2013; 113: 8104. https://doi.org/10.1021/cr300491e 
[26] McIntosh S, Gorte RJ. Chem Rev. 2004; 104: 4845. https://doi.org/10.1021/cr020725g

[27] Lin Y, Zhan Z, Barnett SA., J Power Sources 2006; 158: 1313. https://doi.org/10.1016/j.jpowsour.2005.09.060

[28] Zhu H, Colclasure AM, Kee RJ, Lin Y, Barnett SA.J Power Sources 2006; 161: 413. https://doi.org/10.1016/j.jpowsour.2006.04.101

[29] Bierschenk DM, Pillai MR, Lin Y, Barnett SA. Fuel Cells, 2010; 10: 1129. https://doi.org/10.1002/fuce.201000005

[30] Novik NN, Konakov VG, Archakov IY. Rev Adv Materi Sci. 2015; 40: 188.

[31] Zhao K, Du Y.J Power Sources 2017; 347: 79. https://doi.org/10.1016/j.jpowsour.2017.01.113

[32] Larrondo S, Vidal M, Irigoyen B, Craievich AF, Lamas DG, Fabregas IO, et al. Catal Today, 2005 ; 107 : 53. https://doi.org/10.1016/j.cattod.2005.07.110

[33] Laguna OH, Sarria FR, Centeno MA, Odriozola JA. J Catalysis 2010; 276: 360. https://doi.org/10.1016/j.jcat.2010.09.027

[34] Venkataramana K, Madhusudan C, Madhuri C, Reddy CV. Materials Today: Proceedings 3, 2016 ; 3: 3908. https://doi.org/10.1016/j.matpr.2016.11.048

[35] Ren C, Gan Y, Lee M, Yang C, He F, Jiang Y. et al.J Electrochem Soc. 2016; 163: F1115 https://doi.org/10.1149/2.1271609jes

[36] Ren C, Gan Y, Yang C, Lee M, Dong G, Xue X. J Electrochem Soc. 2017; 164: F722. https://doi.org/10.1149/2.0311707jes

[37] Ren C, Gan Y, Yang C, Lee M, Green RD, Xue X. J Appl Electrochem. 2018; 48: 959. https://doi.org/10.1007/s10800-018-1225-Z

[38] Lee MJ, Jung JH, Zhao K, Kim BH, Xu Q, Ahn BG, et al. J Eur Ceram Soc. 2014; 34: 1771. https://doi.org/10.1016/j.jeurceramsoc.2013.12.042

[39] Panthi D, Choi B, Tsutsumi A. J Solid State Electrochem. 2017; 21: 255. https://doi.org/10.1007/s10008-016-3366-5 